\title{
Study and practice of flipped classroom in optoelectronic technology curriculum
}

Jianhua Shi, Bing Lei, Wei Liu, Tianfu Yao, Wenjie Jiang

Jianhua Shi, Bing Lei, Wei Liu, Tianfu Yao, Wenjie Jiang, "Study and practice of flipped classroom in optoelectronic technology curriculum," Proc. SPIE 10452, 14th Conference on Education and Training in Optics and Photonics: ETOP 2017, 104520R (16 August 2017); doi: 10.1117/12.2265968

SPIE Event: 14th Conference on Education and Training in Optics and Photonics, ETOP 2017, 2017, Hangzhou, China 


\title{
Study and practice of flipped classroom in opto-electronic technology curriculum
}

\author{
Jianhua Shi*, Bing Lei, Wei Liu, Tianfu Yao and Wenjie Jiang \\ College of Opto-electronic Science and Engineering, National University of Defense Technology, \\ Changsha 410073, China
}

\begin{abstract}
"Flipped Classroom" is one of the most pop teaching models, and has been applied in more and more curriculums. It is totally different from the traditional teaching model. In the "Flipped Classroom" model, the students should watch the teaching video afterschool, and in the classroom only the discussion is proceeded to improve the students' comprehension. In this presentation, "Flipped Classroom" was studied and practiced in opto-electronic technology curriculum; its effect was analyzed by comparing it with the traditional teaching model.

Based on extensive and deep investigation, the phylogeny, the characters and the important processes of "Flipped Classroom" are studied. The differences between the "Flipped Classroom" and the traditional teaching model are demonstrated. Then "Flipped Classroom" was practiced in opto-electronic technology curriculum. In order to obtain high effectiveness, a lot of teaching resources were prepared, such as the high-quality teaching video, the animations and the virtual experiments, the questions that the students should finish before and discussed in the class, etc. At last, the teaching effect was evaluated through analyzing the result of the examination and the students' surveys.
\end{abstract}

Keywords: Flipped Classroom, teaching model, opto-electronic technology, teaching video

\section{INTRODUCTION}

The "Flipped classroom" is a new teaching model and different from the traditional teaching model which is "lesson taught in class" and "homework done after class". In the "Flipped classroom", the students acquire the knowledge by watching the teaching videos before class and discuss the difficult and important contents in class. The contents that are flipped include the statuses of teaching and learning, the roles of the teacher and the students, the time and the space of study.

The "Flipped classroom" teaching model is the outcome of the deep amalgamation of the information technology and the classroom teaching. In 1993, Eric Mazur founded the computer-assistant teach, the teacher began to change from "lecturer" into "coach" [1]. In 2000, Maureen J. Lage, the professor of university of Miami, published the paper "Inverting the Classroom: A Gateway to Creating an Inclusive Learning Environment", this means the naissance of the idea of "Flipped Classroom"[2]; In 2007, Jonathan Bergmann, the teacher of Colorado middle school, practice the "Flipped Classroom" "[3]. Since 2010, "Flipped Classroom" has been used in many fields, such as lawyer educating, doctor educating, teacher educating etc. Now, with the development of MOOCs(Massive Open Online Courses) and Microcourses, "Flipped classroom" has been a popular teaching model.

In our university, Opto-electronic Technology is a required course for the student whose major is opto-electronic engineer, optical information or optical engineering. It is so important that plenty of manpower, material resources and finance have been paid on it, and now it has been the excellent course of Hunan province. The course website has been built ${ }^{[4]}$, the teaching videos have been recorded, the animations and virtual experiments have been made. So we decided to practice the "Flipped Classroom" in this curriculum.

\section{CONTENTS OF OPTO-ELECTRONIC TECHNOLOGY}

Opto-electronic Technology is a major course. It is the base of many courses, such as Fiber Optics, Opto-electronic System, Opto-electronic Experiments, etc. Its main contents are the typical radiation source, the important photodetectors,

*gexin7651@sina.com; phone 086-013974942184

14th Conference on Education and Training in Optics and Photonics: ETOP 2017, edited by Xu Liu,

Xi-Cheng Zhang, Proc. of SPIE Vol. 10452, 104520R · (c) 2017 ICO, IEEE, OSA, SPIE

CCC code: $0277-786 X / 17 / \$ 18 \cdot$ doi: $10.1117 / 12.2265968$

Proc. of SPIE Vol. 10452 104520R-1 
the modulation of optical signal, the detect technology, and the typical photoelectric system. Table 1 gives the title of each chapter ${ }^{[5]}$ and figure 1 shows the relation among the knowledge points ${ }^{[6]}$.

Table 1. Contents of Opto-electronic Technology.

\begin{tabular}{|ll|}
\hline \multicolumn{1}{|c|}{ Contents of opto-electronic technology } \\
Chapter 1 Radiation source & Chapter 7 Photoelectric imaging device \\
Chapter 2 Introduction of opto-electronic detector & Chapter 8 Optical signal modulation \\
Chapter 3 Photoconductive detector & Chapter 9 Direct detector and coherent detector \\
Chapter 4 Photovoltaic detector & Chapter 10 Photoelectric detection circuit \\
Chapter 5 Photoelectron emission detector & Chapter 11 Typical photoelectric systems \\
Chapter 6 Thermal detector & \\
\hline
\end{tabular}

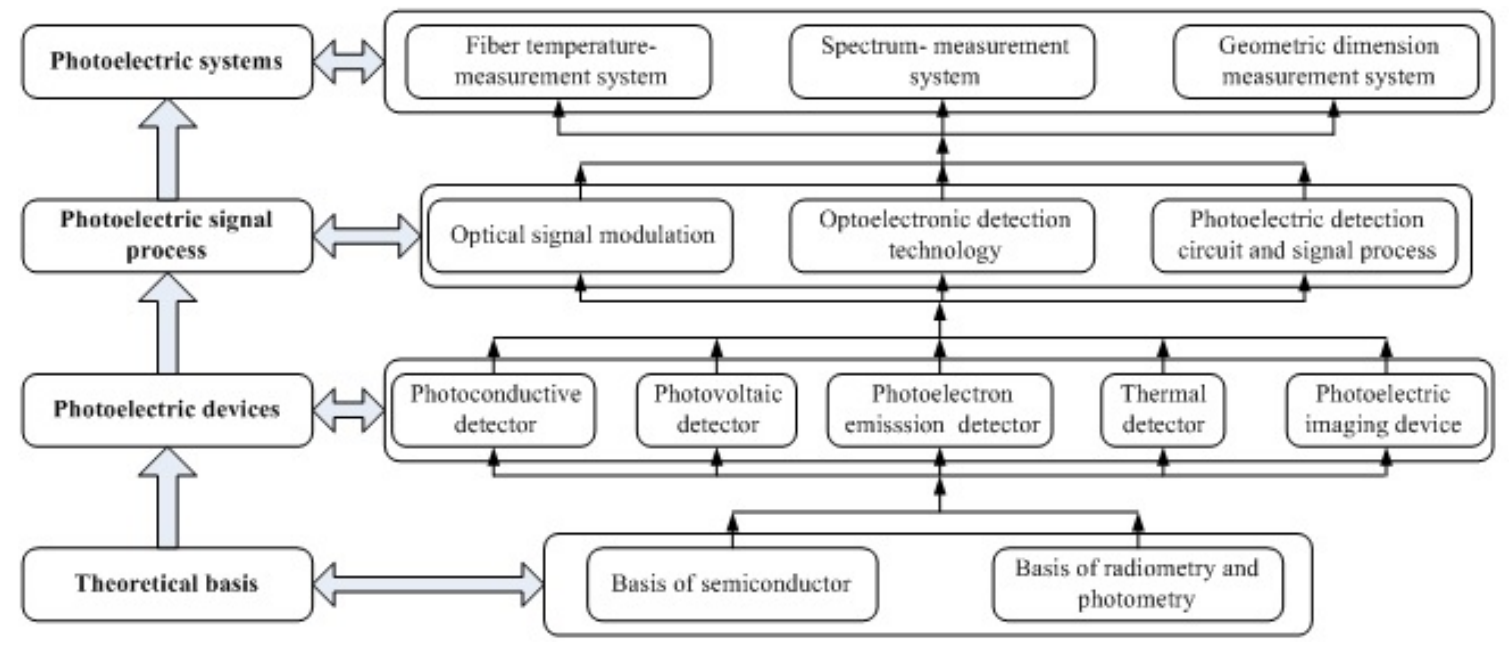

Figure 1. Relations of contents of the Opto-electronic Technology.

\section{TEACHING VIDEOS}

Teaching videos are very important for "Flipped Classroom". The fact that the students have watched the teaching video effectively before the class is the basis of the discussion in the class. In order to meet the different needs of the different students, three series of teaching videos of Opto-electronic Technology have been recorded. Table 2 shows the record types and the teachers. Studio record and screen video record are very compact and each video is shorter than 15 minutes. Classroom teaching records were transcribed when the teacher was giving lessons in the classroom, each video is about 45 minutes. Figure 2 gives the screenshots of studio record, which recorded by Shi Jianhua.

Table 2. Teaching videos of Opto-electronic Technology.

\begin{tabular}{|c|l|l|}
\hline Number & \multicolumn{1}{|c|}{ Record Type } & \multicolumn{1}{|c|}{ Teacher } \\
\hline 1 & Studio Record & Shi Jianhua \\
\hline 2 & Classroom Teaching Record & $\begin{array}{l}\text { Jiang Wenjie, Shi Jianhua, Yang Lijia, } \\
\text { etc. }\end{array}$ \\
\hline 3 & Screencast Video Record & Shi Jianhua \\
\hline
\end{tabular}

\section{FLASH ANIMATIONS AND VIRTUAL EXPERIMENTS}

In order to help the students to understand the important and difficult knowledge points, twelves flash animations and eight virtual experiments have been made. Table 3 gives the title and the knowledge points of each animation. Figure 3 gives the screenshot of each animation. From these animations, the students can understand the structure, the principle, 
the characters and the applications of each important device deeply. Table 4 gives the title and the knowledge points of each virtual experiment, and figure 4 gives the screenshot of each virtual experiment. From these virtual experiments, the students may know the working process of the important systems clearly.

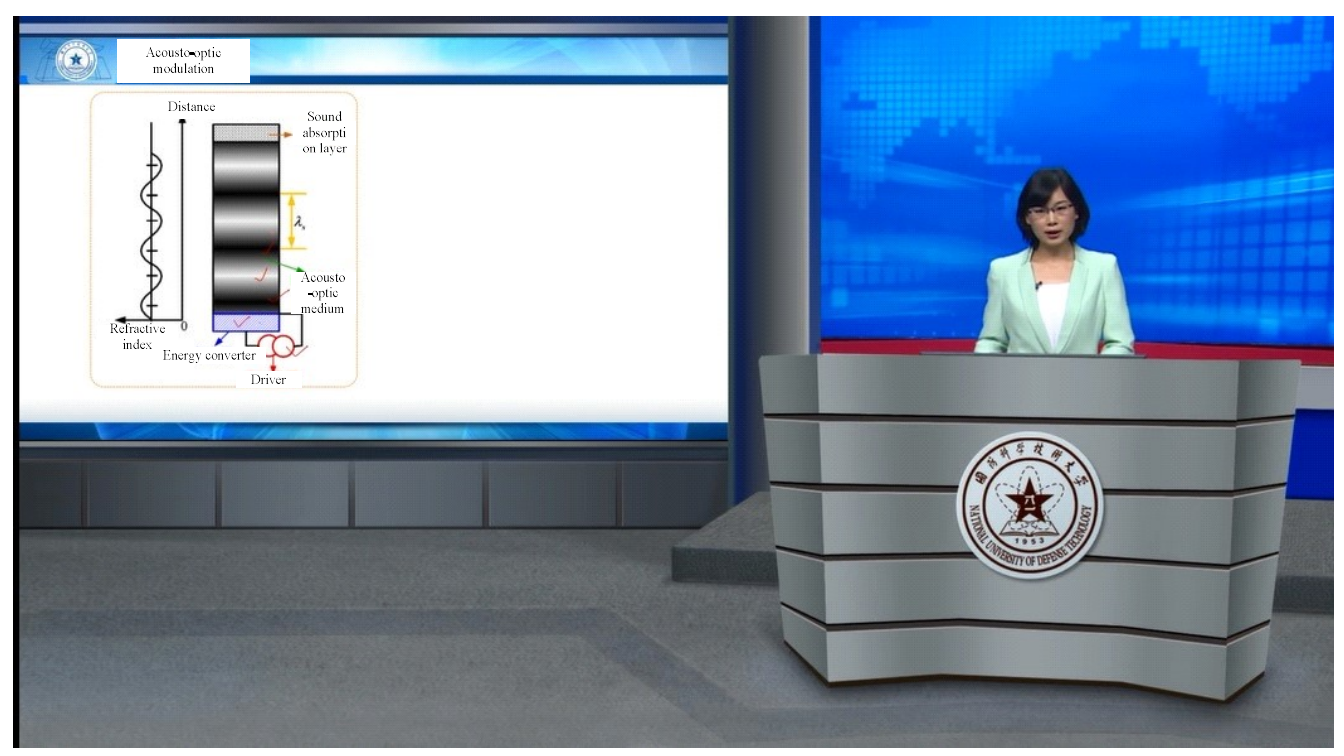

Figure 2. Screenshots of studio recorded by Shi Jianhua.

Table 3. Flash animations of Opto-electronic Technology.

\begin{tabular}{|c|c|c|}
\hline Number & Title & Knowledge points \\
\hline 1 & The automatic exposure of camera & $\begin{array}{l}\text { The principle and characters of photo } \\
\text { resistance }\end{array}$ \\
\hline 2 & Laser semi-active guidance system & $\begin{array}{l}\text { The principle, characters and work process of } \\
\text { laser semi-active guidance system }\end{array}$ \\
\hline 3 & Four-quadrant detector & $\begin{array}{l}\text { Principles of four-quadrant detector and the } \\
\text { photodetector }\end{array}$ \\
\hline 4 & Photomultiplier & The structure and principle of photomultiplier \\
\hline 5 & Transfer of charge packet in CCD & The transfer of the signal in CCD \\
\hline 6 & Transfer of voltage to frequency & $\begin{array}{l}\text { The working process of voltage-frequency } \\
\text { convertor }\end{array}$ \\
\hline 7 & Measuring technique of moire fringe & $\begin{array}{l}\text { The generation of moire fringe, length } \\
\text { measurement by moire fringe }\end{array}$ \\
\hline 8 & Frequency modulation of light intensity & $\begin{array}{l}\text { Frequency control of alternating light } \\
\text { intensity }\end{array}$ \\
\hline 9 & Roundness measurement of spindle's surface & Amplitude modulation of light intensity \\
\hline 10 & $\begin{array}{l}\text { The principle of temperature measurement by } \\
\text { distributed fiber }\end{array}$ & Temperature effect of Raman scattering \\
\hline 11 & $\begin{array}{l}\text { The system of temperature measurement by } \\
\text { distributed fiber }\end{array}$ & $\begin{array}{l}\text { The construction and the working process of } \\
\text { temperature measurement by distributed fiber }\end{array}$ \\
\hline 12 & Modulation by reticle & The construction and the principle of reticle \\
\hline
\end{tabular}



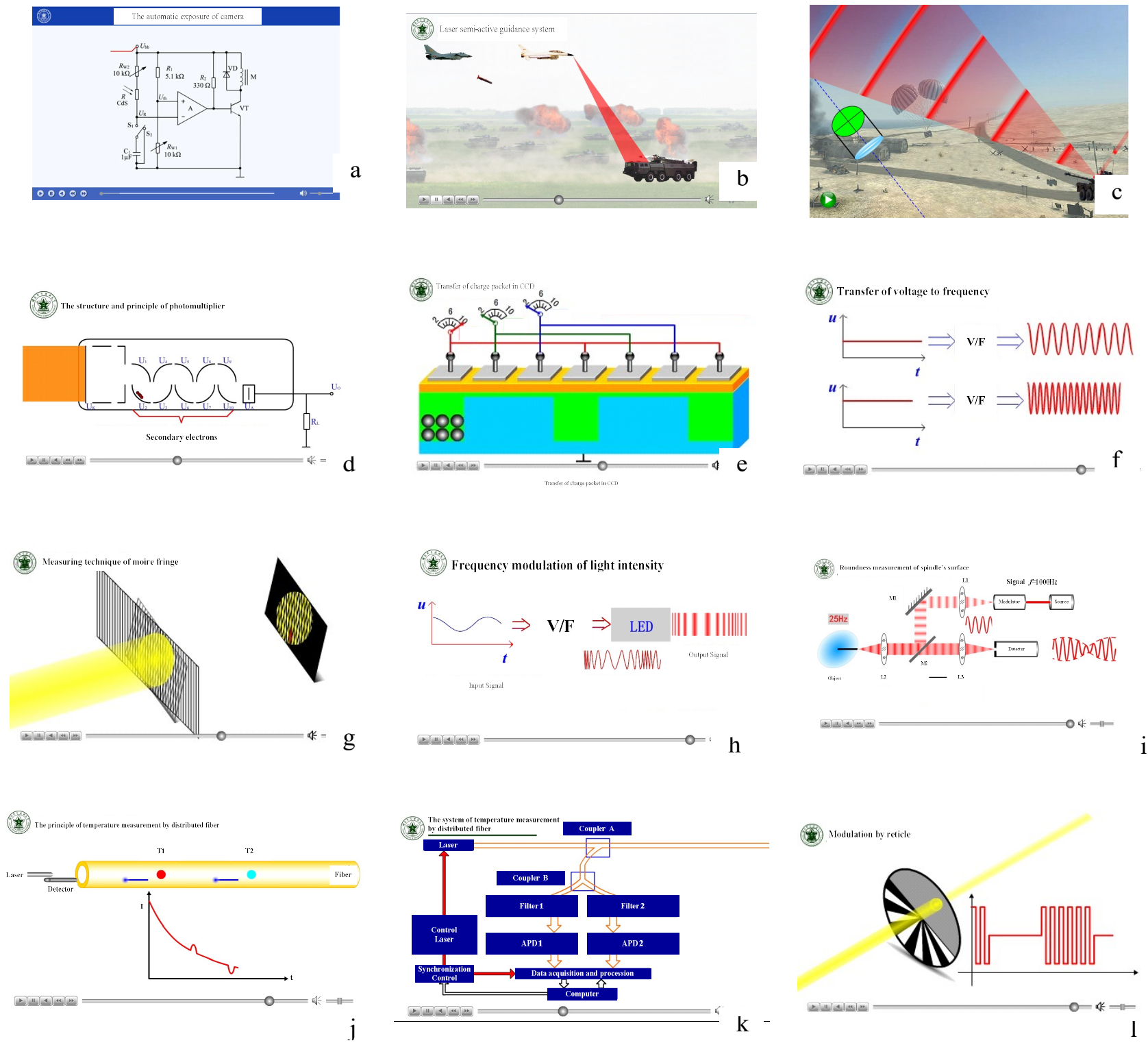

Figure 3. Screenshot of the flash animations: (a) the automatic exposure of camera. (b) Laser semi-active guidance system. (c) Four-quadrant detector. (d) Photomultiplier. (e) Transfer of charge packet in CCD. (f) Transfer of voltage to frequency. (g) Measuring technique of moire fringe. (h) Frequency modulation of light intensity. (i) Roundness measurement of spindle's surface. (j) The principle of temperature measurement by distributed fiber. (k) The system of temperature measurement by distributed fiber. (1) Modulation by reticle. 
Table 4. Virtual experiments of Opto-electronic Technology.

\begin{tabular}{|c|l|l|}
\hline Number & \multicolumn{1}{|c|}{ Title } & \multicolumn{1}{|c|}{ Knowledge points } \\
\hline 1 & Amplitude-modulation wave & $\begin{array}{l}\text { The waveform and the modulation depth of amplitude- } \\
\text { modulation wave }\end{array}$ \\
\hline 2 & Frequency spectrum amplitude-modulation wave & $\begin{array}{l}\text { The frequency characters of amplitude-modulation } \\
\text { wave }\end{array}$ \\
\hline 3 & Frequency-modulation wave & $\begin{array}{l}\text { The waveform and the modulation depth of frequency- } \\
\text { modulation wave }\end{array}$ \\
\hline 4 & The beat frequency of coherent detection & The principle of coherent detection \\
\hline 5 & Frequency spectrum of impulse & Frequency spectrum characters of impulse \\
\hline 6 & $\begin{array}{l}\text { Modulation and demodulation of frequency- } \\
\text { modulation of light intensity }\end{array}$ & $\begin{array}{l}\text { Modulation and demodulation of frequency-modulation } \\
\text { of light intensity }\end{array}$ \\
\hline 7 & $\begin{array}{l}\text { Laser scout, alarm and disturb de key technologies of laser scout, alarm and disturb } \\
\text { amplifier }\end{array}$ & $\begin{array}{l}\text { The detection technology of dim light, the principle of } \\
\text { phase locked amplifier }\end{array}$ \\
\hline 8 & \begin{tabular}{l} 
The detection of dim light by phase locked \\
\hline
\end{tabular} \\
\hline
\end{tabular}
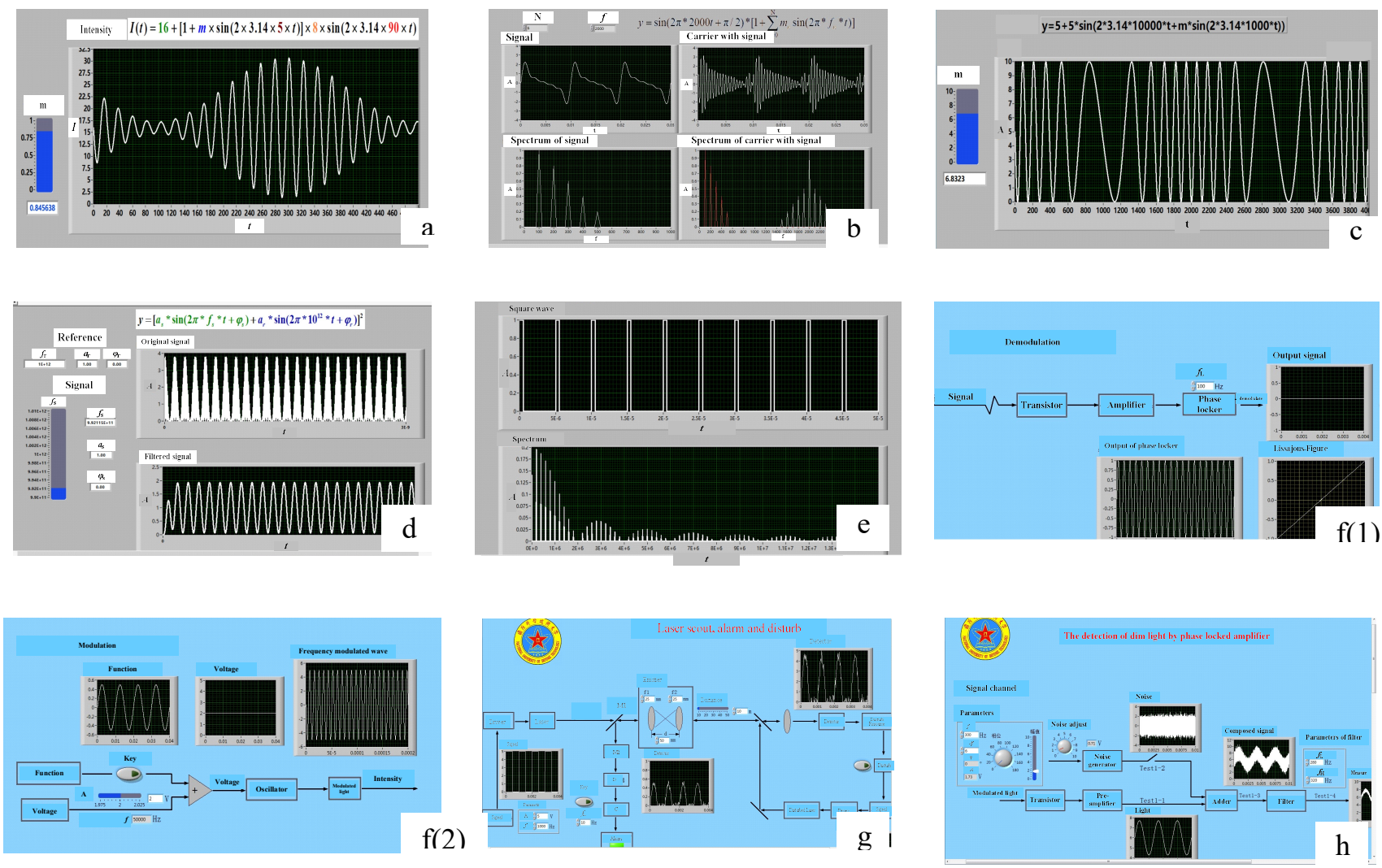

Figure 4. Screenshot of the virtual experiments: (a) Amplitude-modulation wave. (b) Frequency spectrum amplitudemodulation wave. (c) Frequency-modulation wave. (d) The beat frequency of coherent detection. (e) Frequency spectrum of impulse. (f) Modulation and demodulation of frequency-modulation of light intensity. (g) Laser scout, alarm and disturb. (h) The detection of dim light by phase locked amplifier. 


\section{CHAPTERS SELECTION}

In order to compare the "Flipped Classroom" and the traditional teaching model, only the chapter 2 "Introduction of opto-electronic detector" and chapter 4 "Photovoltaic detector" are selected to promote "Flipped Classroom". Other chapters are still taught by the traditional teaching model.

\section{QUESTIONS BEFORE CLASS}

In order to supervise the students to watch the teaching video, some basic questions are put forward and the students should answer these questions before the class. Table 5 gives the questions before class for chapter 2 and chapter 4 .

Table 5. Questions before class for chapter 2 and chapter 4.

\begin{tabular}{|c|l|l|}
\hline Number & \multicolumn{1}{|c|}{ Chapter 2 } & \multicolumn{1}{|c|}{ Chapter 4 } \\
\hline 1 & What is the classification of photo detector? & $\begin{array}{l}\text { Please describe the V-I curve of a PN joint with a } \\
\text { light illuminating. }\end{array}$ \\
\hline 2 & What is the classification of photo detector? & $\begin{array}{l}\text { Please give the current of the photocell when the } \\
\text { circuit is short. }\end{array}$ \\
\hline 3 & What is the effect of the photovoltaic? & $\begin{array}{l}\text { Please give the output voltage of the photocell when } \\
\text { the circuit is open. }\end{array}$ \\
\hline 4 & What is the effect of the photoelectron emission? & Please give the principle of phototransistor. \\
\hline 5 & What is the effect of optothermal? & Please give the structure of PIN PD. \\
\hline 6 & $\begin{array}{l}\text { What is the definition of quantum efficiency? } \\
\text { when an APD is used? }\end{array}$ & $\begin{array}{l}\text { Why the voltage and the temperature should be stable } \\
\text { APD is shorter? }\end{array}$ \\
\hline 8 & How many kinds of noise in a detector? & $\begin{array}{l}\text { Why can a Si-PD not be used to detect a light whose } \\
\text { wavelength is more than 1.1 } 4 \text { mean? }\end{array}$ \\
\hline
\end{tabular}

\section{DISCUSSION IN THE CLASSROOM}

In order to improve the students' comprehension, strengthen the students to use the knowledge to solve the practical matter, some difficult problems are discussed in the classroom. Table 6 gives the questions that are discussed in classroom for chapter 2 and chapter 4.

\section{TEACHING EFFECTIVENESS}

In order to know the teaching effectiveness of the "Flipped Classroom", a questionnaire was prepared and the students must finish the questionnaire before final examination. The result shows that about 80 percent students watched the teaching video before class, most students can understand the $75 \sim 90 \%$ content of the teaching. About $60 \%$ students like the traditional teaching model and about $40 \%$ students like the "Flipped Classroom" teaching model.

The scores of examinations are also analyzed. The result shows that the scoring averages of traditional teaching model and the "Flipped Classroom" were little difference. 
Table 6. Questions discussed in the classroom for chapter 2 and chapter 4.

\begin{tabular}{|c|c|c|}
\hline Number & Chapter 2 & Chapter 4 \\
\hline 1 & $\begin{array}{l}\text { Please describe the difference between the photo } \\
\text { detector and the photo electronic detector? }\end{array}$ & $\begin{array}{l}\text { Why the photovoltaic can't work in the first } \\
\text { quadrant? }\end{array}$ \\
\hline 2 & $\begin{array}{l}\text { Which kind of photo detectors is fit for detecting } \\
\text { the object moving with high speed? }\end{array}$ & $\begin{array}{l}\text { The response time of the photodiode is much } \\
\text { shorter than the photocell, why? }\end{array}$ \\
\hline 3 & $\begin{array}{l}\text { Why the photoconductive detector should made } \\
\text { by the material with high resistance and worked at } \\
\text { the low temperature? }\end{array}$ & $\begin{array}{l}\text { Why the photocell is made by many detached } \\
\text { board? }\end{array}$ \\
\hline 4 & $\begin{array}{l}\text { For photoconductive detector, photovoltaic } \\
\text { detector and photoelectrons emission detector that } \\
\text { made by the same material, whose cutoff } \\
\text { wavelength is longest? }\end{array}$ & $\begin{array}{l}\text { How can we use the photocell to detect the color of an } \\
\text { object? }\end{array}$ \\
\hline 5 & $\begin{array}{l}\text { How can we increase the quantum of a } \\
\text { photodetector? }\end{array}$ & Please design a an amplify circuit for photodiode. \\
\hline 6 & $\begin{array}{l}\text { Why the electric current of a photo detector } \\
\text { changes with the light wavelength? }\end{array}$ & $\begin{array}{l}\text { Please describe the difference between the common } \\
\text { photodiode, the PIN PD and APD. }\end{array}$ \\
\hline 7 & How can we reduce the noise of the detector? & $\begin{array}{l}\text { How can a four-quadrant detector be used to determine } \\
\text { the direction of an object? }\end{array}$ \\
\hline 8 & $\begin{array}{l}\text { Please design an experiment set to measure the } \\
\text { spectrum responsibility of a detector? }\end{array}$ & \\
\hline
\end{tabular}

\section{REFERENCES}

[1] Hao Linxiao, She Yan-dong, "On the implication of flipped classroom for China's contemporary curriculum reform," Comparative Education Review, 2015(5): 80 86(2015)

[2] Maureen J. Lage, Glenn J. Platt, Michael Treglia, "Inverting the Classroom: A Gateway to Creating an Inclusive Learning Environment," 31: 30-43(2000)

[3] http://en.wikipedia.org/wiki/Jonathan_Bergmann\#Flipped_classroom

[4] http://jpkc2010.nudt.edu.cn/gdjs/

[5] Jiang Wenjie and Shi Jianhua, Xie Wenke etc. [Optoelectric technology], Science Press, Beijing, vi-xii(2014)

[6] Shi Jianhua, Ma Haotong, Jiang Wenjie etc. "Research on 'theory-practice-innovation' trinity Network Course", Journal of Higher Education Research, 37(4):84-88(2014)

[7] Shi Jianhua, Duan Chengfang, Hu Haojun etc. "Practice and discussion on Military Opto-Electronic Technology and Application MOOC course”, Computer Engineering \& Science, 36(s2):246-249(2014) 